\title{
Is home care an issue for primary health care? Expert views from Poland and Estonia
}

\author{
KAJA PÕLLUSTE', в-F, LUDMIŁA MARCINOWICZ², B-F, SŁAWOMIR CHLABICZ
}

\author{
${ }^{1}$ Department of Internal Medicine, Institute of Clinical Medicine, University of Tartu, Estonia \\ ${ }^{2}$ Department of Primary Health Care, Medical University of Bialystok, Poland \\ ${ }^{3}$ Department of Family Medicine and Community Nursing, Medical University of Bialystok, Poland
}

A - Study Design, B - Data Collection, C - Statistical Analysis, D - Data Interpretation, E - Manuscript Preparation, $\mathbf{F}$ - Literature Search, $\mathbf{G}$ - Funds Collection

Summary Background. Home care (HC) is placed between the health and social welfare systems, and the clients of HC mostly need health services. Along with other providers, family doctors (FDs) are usually involved in the provision of care.

Objectives. This paper aims to describe and compare the involvement of HC providers to elderly and disabled persons in Poland and Estonia.

Material and methods. This study is part of the international project EURHOMAP (Mapping Professional Home Care in Europe). Data was collected in 2008-2010. Experts from different areas of health and social care were queried by using a questionnaire containing structured case narratives, which were hypothetical descriptions of the situations of elderly or disabled persons living at home and in need of care.

Results. There are a number of HC services, e.g. nursing, medical and social, available in both countries. The application for $\mathrm{HC}$ is mostly made by the patient or a close family member; the point of entry to $\mathrm{HC}$ can differ and depends on the client's primary problem. FDs, together with social workers, play an important role in the provision of HC services in both countries. However, due to a shortage of round-the-clock professional services at a client's home, families are also expected to play a large role in providing HC.

Conclusions. Health care professionals, mainly those working in primary health care, play a remarkable role in access to and provision of HC services. Nevertheless, responsibility for 24-hour care lies, to a large extent, with the client's immediate family. This situation seems to be typical in Eastern European countries.

Key words: home care, primary health care, family doctor, Poland, Estonia.

Põlluste K, Marcinowicz L, Chlabicz S. Is home care an issue for primary health care? Expert views from Poland and Estonia. Fam Med Prim Care Rev 2016; 18(4): 455-459, doi: 10.5114/fmpcr.2016.63701.

\section{Background}

Most countries in the world are faced with an ageing population, which has resulted in an increased need for appropriate health and social support services, including long-term care and services provided in the home [1]. Home care $(\mathrm{HC})$ can also be needed by persons with disabilities, irrespective of age, to support them in their daily living activities [2]. The purpose of $\mathrm{HC}$ is to prevent unmet needs or institutionalization. In general, $\mathrm{HC}$ includes: technical nursing care (e.g. wound care, infusions), domestic aid (e.g. house cleaning, shopping), personal care (e.g. personal hygiene, assistance with meals), rehabilitation care and supportive care [3]. Nevertheless, a majority of $\mathrm{HC}$ clients need health services as well, thus, the family doctor (FD) is usually involved in provision of care [4-6] or is expected to be a coordinator of the care [7]. However, as argued in a recent WHO report [1], health workers are often unprepared to deal with the needs of these patients, and thus, many patients with several health and social needs may suffer from gaps in the coordination of their care.

Historically, paying attention to long-term care, especially to $\mathrm{HC}$, has been less of a priority in Central and Eastern European (CEE) countries, including Poland and Estonia. Since the beginning of the 1990s, major changes in the organization of health services were related to the implementation of modern primary health care (PHC) systems, which was sup- posed to provide more patient-oriented services and to bring the necessary health services closer to the patient [8], as well as to bring together the health and social welfare systems [9]. Development of PHC is well studied in both countries [10, 11]. However, information about the implementation of social care services is very limited, focusing only on specific aspects in Poland [12] or specific user groups in Estonia [13]. Nevertheless, there is increased demand for nursing and $\mathrm{HC}$ services in both countries. In Poland, the proportion of the population aged 65 and older increased from 10.2\% in 1990 to $14.7 \%$ in 2013 [14]. The same trends apply in Estonia - the proportion of the population aged 65+ increased from 11.6\% in 1990 to $18.9 \%$ in 2015 [15]. Moreover, an EU-wide population survey in 2007 showed that professional care at home is preferred by a majority of Estonian and Polish respondents to care in a nursing home [16]. Currently, the proportion of $\mathrm{HC}$ services is increasing in both countries. More detailed descriptions of the current state of $\mathrm{HC}$ in Estonia and Poland are available elsewhere $[17,18]$.

In this paper, we describe the involvement of providers of $\mathrm{HC}$ to elderly and disabled persons in Poland and Estonia, with a focus on the following research questions:

- What types of HC services are available?

- Which professionals are providing HC services?

- What are the differences and commonalities between Poland and Estonia for different types of clients? 


\section{Material and methods}

This study is part of the international project EURHOMAP (Mapping Professional Home Care in Europe), which included 31 European countries and aimed to describe and compare HC in Europe. Data was collected in 2008-2010, and the data gathering process was previously described in detail by Genet et al. [19]. According to the EURHOMAP protocol, $\mathrm{HC}$ was limited only to services provided by professionals in the homes of adult recipients. In the present study, we used data collected by structured case narratives, which were questionnaires containing hypothetical descriptions of the situations of elderly or disabled persons living at home and in need of care [19]. The questionnaire (in Polish and Estonian versions) included 16 questions concerning available HC services, co-payments, assessment of client needs, availability of informal caregivers and the availability of care providers involved in $\mathrm{HC}$. The questionnaire included multiple-choice as well as open-ended questions. Responses to the closed questions were presented as numbers and percentages, and responses to open questions were analyzed using the content analysis technique. The written answers of experts were grouped into categories, and some of them were cited verbatim.

The participants in the study were experts (12 from Poland and 8 from Estonia) in their respective fields, represented by doctors, nurses, social workers and NGO representatives. Respondents were chosen from different areas of health and social care, as selection of key respondents in this manner enables collection of a wide array of expert opinions [20]. The experts answered questions connected with described cases. Each respondent was asked to answer at least two case narratives. Eventually, 34 completed questionnaires were collected in Poland and 16 questionnaires in Estonia (Table 1).

\section{Results}

\section{Types of home care services}

As reported by all respondents, and in accordance with statutory law, every eligible person in both Poland and Estonia is entitled to the following services:

- social care services, including personal care (assistance in bathing, feeding, etc.) and home help (cleaning, washing, preparing meals, etc.);

- specialist services (physiotherapy, occupational therapy, psychotherapy, speech therapy);

- $\quad$ services provided by a family nurse and/or longterm home care nurse;

- subsidies for the purchase or hire of rehabilitation equipment, adult diapers, home adaptations to meet the needs of the disabled person, purchase of a wheelchair and rehabilitation holiday;

- $\quad$ services provided by a FD (home visits, health check-ups);

- $\quad$ home hospice care for persons with a terminal condition;

- financial aid, such as target or periodic benefits, e.g. to buy medications, and nursing aid for the client (all people over the age of 75 are eligible in Poland, along with disabled persons in Estonia irrespective of age);

- counseling provided by social welfare institutions;

- $\quad$ placement in a social welfare home;

- $\quad$ hiring of accessory equipment (e.g. bed, anti-bedsore mattress).

In Poland, some municipalities provide "assistance to the disabled", offering free transportation, but this service is not part of the social care system. Similarly, in Estonia,

\begin{tabular}{|c|c|c|}
\hline Institution & Role, function & $\begin{array}{l}\text { Number of } \\
\text { questionnaires }\end{array}$ \\
\hline \multicolumn{2}{|l|}{ Poland } & $n=34$ \\
\hline Home and residential hospice & general practitioner & 2 \\
\hline Clinic of geriatrics, Medical University & geriatrician & 2 \\
\hline Non-public healthcare institution 1 & nurse, manager & 4 \\
\hline Non-public healthcare institution 2 & nurse, manager & 4 \\
\hline $\begin{array}{l}\text { National consultant in the field of nursing for the chroni- } \\
\text { cally ill and handicapped }\end{array}$ & nurse & 2 \\
\hline National Health Found & nurse, medical specialist & 4 \\
\hline Center for Family Support & manager & 4 \\
\hline Department of Health, Social Care and Community Affairs & director & 4 \\
\hline Department of Social Affairs & member of staff & 2 \\
\hline Non-profit foundation "Caritas Polska" & member of staff & 4 \\
\hline The Polish Red Cross & member of staff & 2 \\
\hline \multicolumn{2}{|l|}{ Estonia } & $n=16$ \\
\hline Family practice & general practitioner & 2 \\
\hline Nursing Care Centre & member of board (home nurse) & 2 \\
\hline Nursing hospital & chairman of board (medical doctor) & 2 \\
\hline County Hospital & social worker & 2 \\
\hline Central hospital & $\begin{array}{l}\text { head of the department of rehabilitation ser- } \\
\text { vices (medical doctor) }\end{array}$ & 2 \\
\hline University hospital & social worker & 2 \\
\hline County government & social worker & 2 \\
\hline City government & head of the health department (medical doctor) & 2 \\
\hline
\end{tabular}


free transportation is available to disabled persons (e.g. to receive ambulatory rehabilitation services); however, the service can be limited and is dependent on the municipality's financial capability.

In both countries, the financial situation of a client's family is also taken into consideration when deciding upon the granting of certain services, especially social security benefits. This financial assessment is also used to help determine the family's ability to co-pay for some services, e.g. purchase of rehabilitation equipment. For example, clients can receive some services free of charge only if their income is below a certain minimum threshold.

\section{Initiative in searching for $\mathrm{HC}$}

Both in Poland and Estonia, usually a close family member (or the client him/herself) undertakes the search for care (79.4\% and $56.3 \%$ of experts' responses in Poland and Estonia, respectively). A FD or another specialist, as well as a nurse or a social worker, can also initiate the process. Neighbors or the patient him/herself, according to the situation, can apply as well. In some cases, a nursing home or hospital can register the patient for $\mathrm{HC}$.

\section{Entry to the services and service providers engaged in care}

The actual application for $\mathrm{HC}$ is mostly submitted by the patient or a close family member $(82.4 \%$ in Poland and $87.5 \%$ in Estonia); health and social care specialists submit applications only in a minority of cases. The point of entry to $\mathrm{HC}$ can differ and depends on whether the client's primary problem is related to health or social care needs (as reported by $41.2 \%$ of experts in Poland and $50 \%$ in Estonia). Nevertheless, $29.4 \%$ of experts in Poland and $31.3 \%$ in Estonia reported that every service has its own point of entry; however, in some cases, all services can be applied for by using a single "window" (29.4\% in Poland and 18.7\% in Estonia).

Although the types of service providers involved in $\mathrm{HC}$ are very similar between the two countries, there are some differences (Table 2). FDs, together with social workers, play an important role in both countries; however, the role of nurses was more expressed in Poland. The involvement of physiotherapists and psychologists was indicated only by
Polish experts. In Estonia, the role of adult children in the provision of $\mathrm{HC}$ was stressed more. The participation of priests and spiritual workers in $\mathrm{HC}$ was also mentioned more often by Polish experts than by their Estonian counterparts. Although health services are free and available both in Poland and Estonia, most experts claimed that the availability of informal caregivers was taken into consideration when making a decision on the granting of services/benefits (in Estonia $93.8 \%$ of responses; in Poland, 58.8\%).

Still, in practice, clients and their relatives in both countries encounter different obstacles in receiving some $\mathrm{HC}$ services. In Poland, the following limitations were noted:

- $\quad$ poor accessibility to home services in small villages (75\% of experts);

- difficulty in providing round-the-clock services by professionals (50\%);

- $\quad$ psychological support for clients and their relatives (53\%).

In Estonia, limitations concerning the following areas were highlighted by the experts:

- $\quad$ provision of round-the-clock personal help by professionals at home, whilst according to Family Law, close relatives (children, grandchildren, parents and grandparents) are obliged to assure personal care of the persons in need (pointed out by all experts); round-the-clock personal help and care is available in nursing homes only;

- $\quad$ psychological support for clients and their relatives (75\% of experts);

- $\quad$ provision of rehabilitation services at the client's home $(50 \%$ of experts).

\section{Discussion}

The organization and funding of $\mathrm{HC}$ services are similar in Poland and Estonia, whereby FDs and nurses play an important role in provision of $\mathrm{HC}$. The breadth of services formally offered in each country is also similar, ranging from personal assistance at the client's home to nursing homes that provide 24-hour care. Moreover, as shown by the current study, family members continue to be important $\mathrm{HC}$ providers in both countries. This latter finding agrees with previous observations in Poland, where the primary care-

Table 2. Persons involved in provision of home care in Poland and Estonia. The numbers (n) and percentages (\%) refer to the respondents who mentioned the person's involvement in home care

\begin{tabular}{|c|c|c|c|c|}
\hline \multirow[t]{2}{*}{ Home care providers } & \multicolumn{2}{|c|}{ Poland $(n=34)$} & \multicolumn{2}{|c|}{ Estonia $(n=16)$} \\
\hline & $n$ & $\%$ & $n$ & $\%$ \\
\hline Nurse & 26 & 76.5 & 7 & 43.8 \\
\hline Family doctor & 25 & 73.5 & 11 & 68.8 \\
\hline Social worker & 24 & 70.6 & 14 & 87.5 \\
\hline Providers of home help (domestic aid) & 22 & 64.7 & 7 & 43.8 \\
\hline Close relative (child/ parent) of the client & 20 & 64.7 & 12 & 75.0 \\
\hline Physiotherapist & 15 & 44.1 & - & - \\
\hline Neighbor & 11 & 32.4 & 4 & 25.0 \\
\hline Friend & 11 & 32.4 & 5 & 31.3 \\
\hline Medical specialist & 6 & 17.6 & 5 & 31.3 \\
\hline Volunteer & 6 & 17.6 & 5 & 31.3 \\
\hline Priest or spiritual worker & 5 & 14.7 & 1 & 6.3 \\
\hline Occupational therapist & 3 & 8.8 & 1 & 6.3 \\
\hline Psychologist & 3 & 8.8 & - & - \\
\hline Home hospice team & 1 & 2.9 & - & - \\
\hline
\end{tabular}


giver of disabled elderly persons was found to be a close relative $[21,22]$ and is the norm expected by a majority of the elderly population [23]. These findings also reflect the attitudes of the Estonian populace. For example, results from a survey in 2007 showed that approximately half of Estonians thought that care for dependent elderly persons should be the responsibility of close relatives. Nevertheless, a majority of Estonians also expressed the opinion that professional care at home would be the best solution for a dependent elderly parent [16], as family members or relatives may not have sufficient knowledge and experience or the capability to provide round-the-clock care. Moreover, the strong involvement in $\mathrm{HC}$ of such informal caregivers as neighbors, friends, voluntaries or priests/nuns should be emphasized.

The purpose of $\mathrm{HC}$ is to provide services enabling people to remain living in their home environment; however, as reported by Bilotta et al. [24], poor quality of personal care may increase the risk for placement in a nursing home. In providing $\mathrm{HC}$ services, there is always the question about the coordination of care. As demonstrated from our study, it is rather uncommon for the client to have a single "window" through which to apply for HC services. Mostly, in both countries, there are multiple points of entry to $\mathrm{HC}$, depending on whether the client's primary problem is related to health or social care needs; in extreme cases, every service may have its own point of entry. This situation is explained by the ways in which services are organized and delivered, some being administered by the health system and others by the social care system. It seems that, as in some other countries [4-7], the FDs in Poland and in Estonia are mostly involved in the care of the patients with a need of HC. Thus, they may have a key role in this process, primarily in provision the appropriate information about other services that might be necessary for the patients and their families.

Besides the FDs and nurses, the role of family members as informal caregivers was also highly stressed by respondents in both countries. Even so, family involvement in home care determines new tasks for doctors and nurses of primary health care. The family as the main care provider for disabled or elderly persons at home requires the support of medical professionals; however, the traditional role of the family has been changing. Adult children seldom live with their ageing parents, which limits their ability to provide care for their parents. As stressed by the respondents, the main concern for the families was the lack of psychological as well as physical support for the provision of roundthe-clock help, but as demonstrated in another study, family caregivers also need counseling, information about service availability and training [25].

This is the first study where the situation of $\mathrm{HC}$ was investigated and compared in two countries in transition. The provision of $\mathrm{HC}$ was studied from the point of view of $\mathrm{HC}$ experts. The samples of experts were rather small, and as such may not represent the opinions of all experts involved in $\mathrm{HC}$ in Poland and Estonia. This can be considered as a limitation of the study. Nevertheless, because the experts were selected according to common criteria, the results can be compared between the two countries.

\section{Conclusions}

Estonia and Poland have a number of similarities in how each organizes and provides HC services. Typically, as in other countries in transition, the $\mathrm{HC}$ services of Poland and Estonia are also in transition. Bridging health and social care, health care professionals, mainly those working in $\mathrm{PHC}$, play a remarkable role in the provision of $\mathrm{HC}$ services. In addition to the patient/client and the family, the FD and/ /or nurse take an early role in home-based care in close cooperation with social workers. However, responsibility for 24-hour care lies, to a large extent, with the client's immediate family. This situation seems to be typical for Eastern European countries.

Acknowledgements. This study is part of the international project EURHOMAP (Mapping Professional Home Care in Europe), which was coordinated by the Netherlands Institute for Health Services Research (NIVEL) and funded by the European Commission (Directorate General SANCO).

Source of funding: This work was funded by the authors' resources.

Conflict of interest: The authors declare no conflict of interests.

\section{References}

1. World report on ageing and health. World Health Organization: Copenhagen; 2015 [cited 5.05.2016]. Available from URL: http://apps.who.int/iris/bitstream/10665/186463/1/9789240694811_eng.pdf?ua=1.

2. World report on disability 2011. World Health Organization: Copenhagen 2011 [cited 5.05.2016]. Available from URL: http:// whqlibdoc.who.int/publications/2011/9789240685215_eng.pdf.

3. Genet N, Boerma W, Kroneman M, et al., eds. Home Care across Europe. Current structure and future challenges. World Health Organization: Copenhagen; 2012 [cited 5.05.2016]. Available from URL: http://www.euro.who.int/_data/assets/pdf_ file/0008/181799/e96757.pdf.

4. van der Plas AG, Vissers KC, Francke AL, et al. Involvement of a case manager in palliative care reduces hospitalisations at the end of life in cancer patients; a mortality follow-back study in primary care. PLoS One 2015; 10(7): e0133197, doi: 10.1371/ journal.pone.0133197. eCollection 2015.

5. Sunde S, Walstad RA, Bentsen SB, et al. The development of an integrated care model for patients with severe or very severe chronic obstructive pulmonary disease (COPD): the COPD-Home model. Scand J Caring Sci 2014; 28(3): 469-477.

6. Armitage N, Trethewie S. Paediatric palliative care - the role of the GP. Aust Fam Physician 2014; 43(4): 176-180.

7. Azuma K, Ohta S. Relations with emergency medical care and primary care doctor, home health care. Nihon Rinsho 2016; 74(2): 203-214.

8. Rozporządzenie Ministra Zdrowia w sprawie świadczeń gwarantowanych z zakresu podstawowej opieki zdrowotnej (Dz.U. z dnia 28 października 2013, poz. 1248).

9. Estonian National Health Plan 2009-2020. Ministry of Social Affairs. Tallinn 2009 [cited 5.05.2016]. Available from URL: https://www.sm.ee/sites/default/files/content-editors/eesmargid_ja_tegevused/Tervis/Aruanded/rta_2009-2020_2012_eng.pdf.

10. Põlluste K, Lember M. Primary health care in Estonia. Fam Med Prim Care Rev 2016; 18(1): 74-77.

11. Strzelecka AK, Nowak-Starz G, Karakiewicz B. Expectations of patients towards a primary care physician, related to the reason for the current visit, with particular emphasis on patients aged 65+. Fam Med Prim Care Rev 2015; 17(3): 215-218.

12. Marcinowicz L, Chlabicz S, Konstantynowicz J, et al. Involvement of family nurses in home visits during an 8-year period encompassing primary healthcare reforms in Poland. Health Soc Care Community 2009; 17(4): 327-334. 
13. Põlluste K, Kallikorm R, Mättik E, et al. Assistive devices, home adjustments and external help in rheumatoid arthritis. Disabil Rehabil 2012; 34(10): 839-845.

14. Central Statistical Office Poland [cited 5.05.2016]. Available from URL: http:// www.stat.gov.pl.

15. Statistical Office of Estonia [cited 5.05.2016]. Available from URL: http://www.stat.ee/.

16. TNS Opinion \& Social. Health and long-term care in the European Union: Special EUROBAROMETER 283.7. 2007. Brussels: Directorate-General for Employment, Social Affairs and Equal Opportunities and coordinated by Directorate-General for Communication.

17. Põlluste K, Chlabicz S. Estonia. In: Genet N, Boerma W, Kroneman M, et al., eds. Home Care across Europe. Case studies. Copenhagen: World Health Organization; 2013: 79-85.

18. Chlabicz S, Marcinowicz L, Mojsa W. Poland. In: Genet N, Boerma W, Kroneman M, et al., eds. Home Care across Europe. Case studies. World Health Organization: Copenhagen; 2013: 214-222.

19. Genet N, Kroneman M, Boerma WGW. Explaining governmental involvement in home care across Europe: an International comparative study. Health Policy 2013; 110(1): 84-93.

20. Patton MQ. Qualitative research \& evaluation methods. 3rd ed. Thousand Oaks: Sage Publications; 2002.

21. Bien B, Wojszel ZB, Wilmańska J, et al. Starość pod ochroną. Opiekunowie rodzinni niesprawnych osób starszych w Polsce. Porównawcze studium środowiska miejskiego i wiejskiego. Kraków: Oficyna Wydawnicza Text; 2001.

22. Borowiak E, Kostka T. Comparative characteristics of the home care nursing services used by community-dwelling older people from urban and rural environments. J Adv Nurs 2013; 69(6): 1259-1268.

23. Halicka M, Pędich W. Działania samopomocowe ludzi starszych - badania panelowe w Białymstoku. Białystok: Akademia Medyczna; 1997: 59.

24. Bilotta C, Nicolini P, Vergani C. Quality of private personal care for elderly people in Italy living at home with disabilities: risk of nursing home placement at a 1-year follow-up. Health Soc Care Community 2009; 17(6): 543-547.

25. Tin Ng G. Support for family caregivers: what do service providers say about accessibility, availability and affordability of services? Health Soc Care Community 2009; 17(6): 590-598.

Tables: 2

Figures: 0

References: 25

Received: 18.05.2016

Revised: 19.06.2016

Accepted: 20.06.2016

Address for correspondence:

Kaja Põlluste, MD, PhD

Department of Internal Medicine

Institute of Clinical Medicine

University of Tartu

L. Puusepa 8

51014 Tartu

Estonia

Tel.: +372 7318616

E-mail: kaja.polluste@ut.ee 